\title{
Genetic Variation in Resistance to Inflammation and Infectious Disease
}

\author{
Heng-wei Cheng \\ Livestock Behavior Research Unit, USDA-ARS/Purdue University, \\ West Lafayette, \\ USA
}

\section{Introduction}

Genes determine functions of the neuroendocrine and immunological systems that affect an animal's ability to cope with stress, resulting in resistance or susceptibility to infection and inflammation. In this study, genetic variation in responses to lipopolysaccharide (LPS) challenge was examined in chicken lines divergently selected for high (HGPS) and low (LGPS) group productivity and survivability resulting from cannibalism and flightiness in colony cages and in a Dekalb XL (DXL) commercial line selected individually for egg production. Six-week-old chicks were randomly assigned to control or experimental groups and were injected intravenously with Escherichia coli LPS (5 mg/ $\mathrm{kg} \mathrm{BW)} \mathrm{or} \mathrm{distilled} \mathrm{saline}$ (control). Sickness responses were measured at 6, 12, 24, 48, and $72 \mathrm{~h}$ following injection ( $n=10 /$ at each point in time for each line). Although LPS induced widespread sickness symptoms in all of the treated chicks, the reactions were in a genotypic- and phenotypicspecific manner. Compared to both LGPS and DXL chicks, HGPS chicks had acute, transient behavioral and physical changes with less effect on body weight (BW) gain and organ development as well as core temperature, which were in the order HGPS $<$ DXL $<$ LGPS. The effects of heritable factors and LPS challenge on the differential responses among the present lines may reflect each line's unique adaptability to stress and resistance to infection and inflammation. The results suggest that the present chicken lines may provide a new animal model for biomedical investigation on the effects of genetics, epigenetics, and geneenvironmental interactions on physiological homeostasis in response to stress and inflammatory disorders as well as infectious disease.

\section{Aging and inflammation}

Aging is a complex biological process characterized by decline of the functions of various biological systems through the lifetime in an organism. Especially, the decline in the functions of the immune system results in an immune-senescence status (i.e., the coexistence of inflammation and immunodeficiency), with a low-grade chronic inflammation (so called inflamm-aging effect) (Franceschi et al., 2000; Gruver et al., 2007; Salvioli et al., 2006). In humans, inflamm-aging is characterized by the up-regulation of the inflammatory response, resulting in over expressing pro-inflammatory cytokines, such as interleukin (IL)-1, IL-6, IL12, tumor necrosis factor (TNF)-alpha, and interferon (IFN)-alpha and IFN-beta 
(Bruunsgaard and Pedersen, 2003; Salvioli et al., 2006). The aging process also causes an increase in cortisol concentrations due to over activation of the hypothalamus-pituitaryadrenal (HPA) axis by various specific and non-specific stressors (Sergio, 2008). Agingassociated changes in immunity and stress reaction systems increase the risk of infection and promote inflammation, which underlies the biological mechanisms of age-related inflammatory diseases (Agrawal et al., 2010; Cevenini et al., 2010; Chung et al., 2011). Nonsteroidal anti-inflammatory drugs (NSAIDs) are commonly used in the elderly for the treatment of fever, headache, pain, and pain associated with inflammation (Table 1). However, aging-associated physiological changes, such as alterations in pharmacokinetics and impaired homeostasis, and drug interactions, lead to worse the side-effects profile of NSAIDs (Bennett, 1999; Buffum and Bufum, 2000).

\begin{tabular}{|l|l|l|l|}
\hline Common drugs & Characteristics of Aging & Common treatments & $\begin{array}{l}\text { Impact of NSAIDs } \\
\text { during aging1,2 }\end{array}$ \\
\hline $\begin{array}{l}\text { Nonselective } \\
\text { NSAIDs }\end{array}$ & a low-grade systemic & Pain, fever, headache & $\begin{array}{l}\text { Gastrointestinal tract: } \\
\text { ulcers and bleeding }\end{array}$ \\
\hline Salicylates & $\begin{array}{l}\text { Inflammation with } \\
\text { increased }\end{array}$ & $\begin{array}{l}\text { Inflammation in } \\
\text { rheumatoid }\end{array}$ & $\begin{array}{l}\text { Renal tract: acute renal } \\
\text { impairment }\end{array}$ \\
\hline $\begin{array}{l}\text { Propionic acid } \\
\text { derivatives }\end{array}$ & $\begin{array}{l}\text { Pro-inflammatory } \\
\text { cytokines }\end{array}$ & $\begin{array}{l}\text { Arthritis and } \\
\text { osteoarthritis }\end{array}$ & Liver: hepatotoxicity \\
\hline $\begin{array}{l}\text { Acetic acid } \\
\text { derivatives }\end{array}$ & $\begin{array}{l}\text { such as IL-1, -6, -12, } \\
\text { TNR-a }\end{array}$ & Neuromuscular disorder & $\begin{array}{l}\text { Others: cardiovascular, } \\
\text { hematological }\end{array}$ \\
\hline $\begin{array}{l}\text { Enolic acid } \\
\text { derivatives }\end{array}$ & $\begin{array}{l}\text { and overexpression of } \\
\text { free }\end{array}$ & $\begin{array}{l}\text { Musculoskeletal } \\
\text { conditions }\end{array}$ & $\begin{array}{l}\text { and CNS effects and } \\
\text { photosensitivity }\end{array}$ \\
\hline $\begin{array}{l}\text { Fenamic acid } \\
\text { derivatives }\end{array}$ & $\begin{array}{l}\text { Radicals, such as NO } \\
\text { and ROS }\end{array}$ & and Alzheimer's disease & \\
\hline Selective NSAIDS & and CRP, contributing to & & $\begin{array}{l}\text { Neurodegenerative } \\
\text { diseases }\end{array}$ \\
\hline Celecoxib & & & \\
\hline
\end{tabular}

1, The common side-effects of NSAIDs in the elderly persons, resulting from, a few examples, agerelated alterations in pharmacokinetics, impaired homeostasis, and drug interactions.

2, The information presented in the table is summary from the following references: Bennett, 1999; Buffum and Buffum, 2000; Candore et al., 2010; Capone et al., 2010; Gruver et al., 2007; Johnson and Day, 1991; Lipton et al., 2007; Maroon et al., 2010; McGeer and McGeer, 2004; Menkes, 1989; Salvioli et al., 2006; Sastre and Gentleman, 2010; Sherman et al., 2005; Tiihonen et al., 2008.

$\mathrm{COX}=$ cyclooxygenase; $\mathrm{CRP}=\mathrm{C}$-reactive protein; $\mathrm{IL}=$ interleukin; $\mathrm{NO}=$ Nitric oxide; $\mathrm{NSAIDs}=$ Nonsteriodal anti-inflammatory drugs; ROS $=$ Reactive oxygen species .

Table 1. The impact of common anti-inflammation dugs during aging and age-related inflammatory disorders

\subsection{Inflammation and stress}

Inflammation has been termed as: a localized protective response to various harmful stimuli, such as tissue injury or pathogens invasion, which serves to destroy, dilute, or wall off both the injurious agent and the injured tissue. Recently, inflammation has also been 
defined as a balanced biological process between apoptosis ('Yin') and wound healing ('Yang') for acute inflammation; and lost of the balance for chronic inflammation, i.e., mismatched the biological signals during apoptotic and wound healing processes, resulting in disrupting the protective mechanisms of the immune system (Khatami, 2008, 2011). In general, inflammation, as a part of the evolutionary program, is a critical defense mechanism to pathogenic viruses and bacteria; and inflammatory response is a non-specific response of the tissues of an organism. Normally, inflammation facilitates the organism to return to physiological homeostasis to permit survival while uncontrolled inflammatory response contributes to chronic conditions of pathophysiological changes seen during aging (Vasto et al., 2007).

Stress is defined as: any disruption of an animal's homeostatic equilibrium requiring the animal to make some response to maintain its psychophysiological integrity (Hurnik et al., 1995). Stress and inflammatory response evoke the similar somatosensory pathways to signal the brain, and then the brain sends integrated information to the subcortical centers, such as the hypothalamus, regulating final active organs, such as immune cells ( $\mathrm{T}$ and $\mathrm{B}$ lymphocytes and macrophages) and the adrenal glands to regulate the organism's immune and stress responses (Carrier et al., 2005; Sternberg, 2006; McNaull et al., 2010).

Inflammatory response has been considered as a part of stress response. There is a bilateral communication between the immune and neuroendocrine systems (Turnbull et al., 1999; Cohen and Cohen, 1996). For example, various internal and external specific and nonspecific stressors induce an increase in releasing cytokines from immune cells during the aging process. The released cytokines bind to their receptors on neurons, affecting the activity of the HPA axis, causing an increase in cortisol concentrations with age. Cortisol, at a physiological level, acting as a potent immune regulator and an anti-inflammatory agent, is necessary for reducing tissue damage and injury. Age-related increase in cortisol concentrations, causing an imbalance between inflammatory response and antiinflammatory networks, is a major determinant of immune-senescence observed during aging (Bauer, 2008). Immune-senescence, resulting from lifelong chronic antigenic load (allostatic load), leads to a low-grade chronic pro-inflammatory status. Previous studies have evidenced that the antigenic load to individuals exposed throughout lifetime impacts greatly on immune performance and stress response in late life (Pawelec and Larbi, 2008). Due to inherent differences in the capability to maintain physiological homeostasis in response to internal and external stimuli, the interaction of environmental factors with genetic variations determines the phenotypes of the aging process in organisms.

\subsection{Inflammation and genetic characters}

Aging process and rate of age-associate diseases in humans and other animals is not uniform. It is depended on internal (genetic heterogeneity) and external (environment) factors (Vogt et al., 2008; Turko et al., 2011). There are two types of genetic variations affecting the aging process and susceptibility, progression, and severity of aging diseases: 1) the gene sequence (genotype or phenotype) and 2) the modifications of DNA and DNA associated proteins (epigenetics).

Genes regulate patterns of cellular processes and determine the functions of the immune and neuroendocrine systems in controlling an animal's coping strategy and productivity. There are genetic basis in variations of the polymorphism in the promoter regions of the genes encoding pro-inflammatory cytokines and inflammatory mediators (Loktionov, 2003; 
Naumova et al., 2004; Pes et al., 2004). Genetic background has been proposed as a major contributor for the differences in stress response within and among species (intra- and interindividuals' difference) (Knight, 2005; Pastinen and Hudson, 2004). Molecular basis of lowgrade, sub-clinical inflammation is a major risk factor for exacerbating the aging process and its associated disease.

Inheritance is not restricted to DNA sequence. Epigenetics plays a key role in producing viable offspring by passing epigenetic information to progeny (Migicovsky and Kovalchuk, 2011). Similarly, during aging process, a chronic low-grade inflammation status is also related to a trans-generational gene expression via heritable epigenetic mechanisms (vel Szic et al., 2010). Epigenetics means 'above the genetics', used to define the change in gene expression occurring without a change in primary DNA sequence (Lu et al., 2006; Duff, 2007; Mill J 2011). There is growing evidence that epigenomic variability mediates the variation in susceptibility to various diseases during the aging process (Hatchwell and Greally, 2007; Tang and Ho, 2007). Several epigenetic mechanisms associated with phenotypic variations have been identified, including DNA methylation (epimutations), histone modifications, and RNA-mediated pathways from non-coding RNAs, notably silencing RNA (siRNA) and microRNA (miRNA) expression (Wilson 2008; Baccarelli and Bollati, 2009; Krishna et al., 2010). Epigenetic changes are heritable across generations and under environmental influence. Environmental factors, such as lifestyle choices, may result in conflict with the programmed adaptive changes or genomic imprinting made during early development, leading to disease in later life, especially those involving the inflammatory diseases (Petronis, 2001; Pearce et al., 2006; Bayarsaihan, 2011).

\subsection{Lipopolysaccharide (LPS) and inflammation}

Lipopolysaccharide (LPS) is an integral component of the outer membrane (cell wall) of Gram-negative bacteria. Lipopolysaccharide as an endotoxin, is ubiquitous in the external environment; and, as a "hormone", is released from the gastrointestinal tracts in response to a variety of stressors. In a host, LPS, invaded from outside or absorbed from the gastrointestinal tracts, binds to the host's plasma proteins, such as albumin and soluble CD14, to form monomeric particles. The monomeric particles interact with specific surface receptors of host cells, such as Toll-like receptor 4 (TLR4), to activate the intracellular signaling pathways to initiate gene transcription to disrupt the host's innate immune system, resulting in local and or systemic inflammatory reactions (Alexander and Rietshel, 2001; Fessler et al., 2002). Previous studies have shown that LPS induces release of proinflammatory cytokines, adhesion molecules, and acute phase reactants from various cells of the innate immune system, stress hormones, such as CRF and cortisol, from the HPA axis, and catecholamines, i.e., epinephrine and norepinephrine, from the automatic nervous system (the sympathetic and parasympathetic systems) to facilitate the resolution of inflammation (Black and Garbutt, 2002; Marshall, 2005).

Lipopolysaccharide has been implicated as the bacterial product which is responsible for the clinical syndrome of inflammation and infectious disease. Experimentally, administrated LPS causes sickness symptoms including fever, reduction of weight gain and food intake as well as changes of behavior in animals including birds (Xie et al., 2000; Koutsos and Klasing, 2001). In mammals, LPS-induced acute phase response is species and individual dependent (Leininger et al., 1998). Recent findings suggest that birds show many similar response patterns to LPS-immune challenge as mammals (Xie et al., 2000; Koutsos and Klasing 2001). In my lab, chicken has been used as an animal model for detecting the effect of genetic variation on animals' stress response and disease resistance. 


\subsection{Chicken as an animal model for genetic basis of variations in Inflammation}

Chickens is a useful animal models in the assessment of the effects of genetic-environmental interactions on psychopathological stress and inflammation, since a chicken can have more than three hundred offspring with similar genetic characteristics within a lifespan of approximately 60 weeks. In addition, the chicken's immune and HPA systems display similar functions in pathogenic and stress response as those in mammals (Larson et al., 1985; Savory and Mann, 1997). Chickens have been used as animal models in various clinical and psychopharmacological studies (Norman, 1990; Johnson, 1998; Dubousset and Machida, 2001). Functional integrations among behavior, physiology, and morphology may create suites of traits that are simultaneously acted upon by selection. Recently, a selection program termed "group selection" was introduced (Muir, 2005; Muir and Schinckei, 2002; Cheng and Muir, 2005). The advancement of the program is that it allows selection on production traits but takes into account competitive interactions in a group setting. The program focuses on gene(s), environment, and genetic-environmental interactions, by which, it turns "survival of the fittest" with emphasis on the individuals to "survival of the adequate" with emphasis on the group, by which antisocial behaviors are overcome.

A genetic basis of differentially regulated behavior and physical indexes, in response to social stress, has been found in the chickens from White Leghorn lines selected for high (HGPS) or low (LGPS) group productivity and survivability in colony cages (Muir and Craig, 1998; Cheng et al., 2001a). Group productivity was based on an average rate of lay whereas survivability was based on days of survival. Chickens were not beak-trimmed and high light intensity was used to provide conditions that allowed expression of aggressive behavior with resulting stress and productivity impacts (Craig et al., 1999). Under these housing conditions, the HGPS line (previously named KGB, the Kinder, Gentler Bird) showed an improved rate of lay, survival and feather score as well as reduced cannibalism and flightiness compared to hens from the non-selected control line, Dekalb XL (DXL) line, and reversed selected LGPS line (Cheng et al., 2001a). HGPS hens also had better and faster adaptations to various stressors such as social, handling, cold, and heat in multiple-hen cages (Hester et al., 1996a, b, and c). In addition, HGPS hens displayed a greater cell-mediated immunity with a higher ratio of CD4:CD8, whereas LGPS hens exhibited eosinophilia and heterophilia and had a greater ratio of heterophil:lymphocyte (H/L) (Cheng et al., 2001b). Both eosinophilia and H/L have been used as stress indicators in animals including chickens (Gross and Siegel, 1983; Woolaston et al., 1996; Hohenhaus et al., 1998). Collectively, genetic selection has created the lines with significantly different phenotypes, each of which has unique characteristics in physical indexes, behavior, immunity and resistance to stressors (Table 2), which are likely due to differential stress adaptation of the HPA axis and immune system. Based on our and others studies we hypothesize that gene(s) and gene-environmental interactions affect immunity and neuroendocrine functions, which in turn alters the animal's stress coping ability and wellbeing.

In one of our studies, the role of LPS on evoking inflammatory response in those selected lines was examined. One-day-old chicks from the HGPS, LGPS and DXL line were used in the study. Female chicks ( $n=60$ per line), at 6 weeks of age, were randomly divided into saline control and experimental groups. Experimental chickens were injected intravenously with $0.2 \mathrm{~mL}$ of sterile saline reconstituted LPS at an approximate dose of $5.0 \mathrm{mg} / \mathrm{kg}$ of body weight. The saline control chicks were handled the same as the experimental chicks except that they were injected intravenously with $0.2 \mathrm{~mL}$ of sterile saline. 


\begin{tabular}{|c|c|c|c|c|}
\hline \multirow[t]{2}{*}{ Stressors } & \multicolumn{3}{|c|}{ Birds } & \multirow[t]{2}{*}{ References } \\
\hline & HGPS & LGPS & DXL & \\
\hline \multicolumn{5}{|l|}{ Single-bird cage } \\
\hline Immunity & high & Low & -1 & Cheng et al., 2001a \\
\hline Production & high & Low & - & Cheng et al., 2011b \\
\hline Mortality & Low & High & - & Cheng et al., 2001b \\
\hline Level of DA, EP, 5-HT & Low & High & - & Cheng et al., 2001b \\
\hline \multicolumn{5}{|l|}{ Multiple-hen cages ${ }^{2}$} \\
\hline Social environment & $\begin{array}{c}\text { Great } \\
\text { adaptation }\end{array}$ & - & $\begin{array}{c}\text { Low } \\
\text { adaptation }\end{array}$ & Hester et al., 1996a \\
\hline $\mathrm{H} / \mathrm{L}$ ratio & No change & - & Increased & Hester et al., 1996a \\
\hline Handling stress & Low & - & High & Hester et al., 1996b \\
\hline Production & High & - & Low & Hester et al., 1996b \\
\hline Cold exposure & Resistant & - & Susceptive & Hester et al., 1996b \\
\hline Heat exposure & Resistant & - & Susceptive & Hester et al., 1996b \\
\hline \multicolumn{5}{|l|}{ Others } \\
\hline Social stress & Low & High & High & Cheng, et al., 2002, 2003a,b \\
\hline Immune challenge & Low & High & High & Cheng et al., 2004a,b \\
\hline Transportation stress & Low & High & High & Cheng \& Jefferson, 2008 \\
\hline
\end{tabular}

1, Birds were housed in 12 hens per cage without beak trimming.

$2-$, Did not compare in the studies.

3, Immune reaction followed Escherichia coli lipopolysaccharide challenge.

5-HT= Serotonin; $\mathrm{DA}=$ Dopamine; $\mathrm{DXL}=$ Dekalb XL line; $\mathrm{EP}=$ Epinephrine; $\mathrm{H} / \mathrm{L}$ ratio $=$ Heterophil to lymphocyte ratio, as stress indicator; HGPS (also called KGB; kind, gentle birds, previously) $=$ High group productivity and survivability; LGPS (also called MBB; mean, bad birds, previously).

Table 2. The differences between the selected birds in responses to various stressors.

\section{Genetic variations in LPS-induced inflammation}

\subsection{The LPS-induced different changes in body weight and organ weight in different chicken lines}

Present study demonstrated that LPS-induced immune stress differently affected chickens' growth among the HGPS, LGPS, and DXL lines. In DXL chicks, change in body weight (BW) gain exhibited a biphasic pattern, i.e., a greater reduction of BW gain at $6 \mathrm{~h}$ postinjection $(P<0.05)$ and a tendency for reduction of BW gain at $24 \mathrm{~h}$ post-injection $(P=0.08)$, followed by a full recovery at $48 \mathrm{~h}$ post-injection (Figure 1). Compared to DXL chicks, LGPS chicks, but not HGPS chicks, had a similar biphasic pattern of reduction of BW gain in response to LPS immune challenge. In LGPS chicks, reduction of BW gain was greater at both $6 \mathrm{~h}$ and $24 \mathrm{~h}$ post-injection $(P<0.05)$ and did not reach a positive BW gain at $72 \mathrm{~h}$ postinjection. In contrast, HGPS chicks did not have a reduction of BW gain until $24 \mathrm{~h}$ postinjection $(P<0.05)$, followed by a completive recovery at $48 \mathrm{~h}$ post-injection $(P>0.05)$, and reached a positive $\mathrm{BW}$ gain from $48 \mathrm{~h}$ to $72 \mathrm{~h}$ post-injection. 


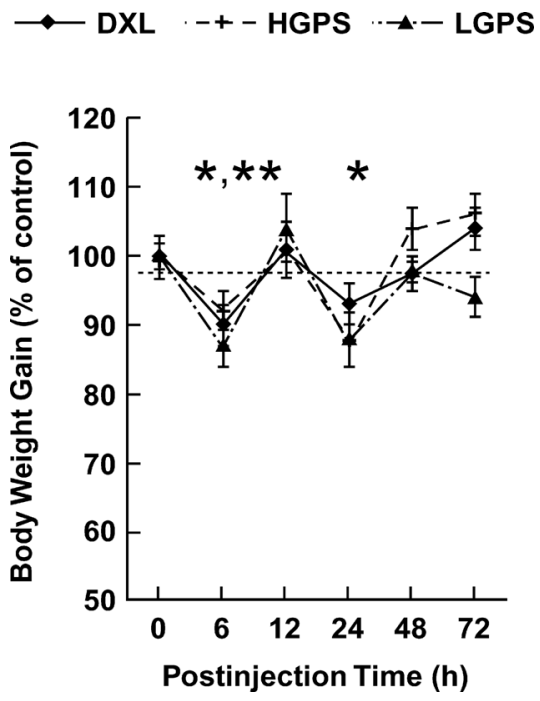

Fig. 1. Differential regulation of BW gains in different chicken lines following lipopolysaccharide (LPS) intravenous injection. The HGPS and LGPS hens were selected for high or low group productivity and survivability, respectively, and the DXL was commercial chicken line. Compared to BW from their respective controls, the BW gain was significant reduced in DXL chicks at $6 \mathrm{~h}$ post injection $(P<0.05)$; in LGPS chicks at both 6 and $24 \mathrm{~h}$ post injection $(P<0.05)$, and in HGPS chicks at $24 \mathrm{~h}$ post-injection $(P<0.01) .{ }^{*}=P<0.05$ and $^{* *}=P<0.01(\mathrm{n}=10 /$ at each period in time for each line).

The interactions of genetic-LPS challenge on chicks' growth among the present chicken lines were also found in their organ development. Compared to each line's respective controls, spleen weight increased in DXL chicks at $48 \mathrm{~h}$ post-injection and reached a peak at $72 \mathrm{~h}$ postinjection $(P<0.05$ and $P<0.01$, respectively, Figure $2 \mathrm{a})$, while LPS-induced increases in spleen weight were not detected in both HGPS and LGPS chicks until $72 \mathrm{~h}$ after injection $(P<0.05)$. The LPS injection also resulted in a differential change of liver weight among the lines (Figure $2 b)$. Compared to each line's respective controls, the LPS-induced increase in the liver weight was found only in LGPS chicks from 12 to $48 \mathrm{~h}$ post-injection $(P<0.01$ and $P<0.05$, respectively, Figure $2 b)$. There were no changes in the heart weight in both DXL and HGPS chicks at any time measured $(P>0.05)$ while LGPS chicks had an increased heart weight during the entire treatment period, with a peak at $72 \mathrm{~h}$ post-injection $(P<0.05$ and $P<0.01$, respectively, Figure $2 \mathrm{c})$. The LPS-induced increase in adrenal weight was found in LGPS chicks at $6 \mathrm{~h}$ postinjection $(P<0.05$ and $P>0.05$, respectively, Figure $2 \mathrm{~d})$ while adrenal weight was not changed in HGPS and DXL chicks during the entire observed period $(P>0.05)$.

The present results showed that, compared to both LGPS and DXL chicks, HGPS chicks had a delayed and transient reduction of BW gain and mild changes in organ development in response to LPS challenge (Figures 1and 2). The data confirmed that the acute toxicity of LPS induced sickness symptoms including reduction of BW gain and changes in organ development in animals, but the effect of LPS on chickens was stain and time dependent. Similar to the present results, a genetic basis of different effects of LPS injection on BW gain was also reported by Parmentier et al. (1998). In their study, they found that although LPS injection induced an acute, transient reduction of BW weight in all of the chicken lines, 
chickens selected for high antibody response to sheep red blood cells (SRBC) had a higher percentage of BW gain than chickens selected for low antibody response to SRBC and a random bred control line.
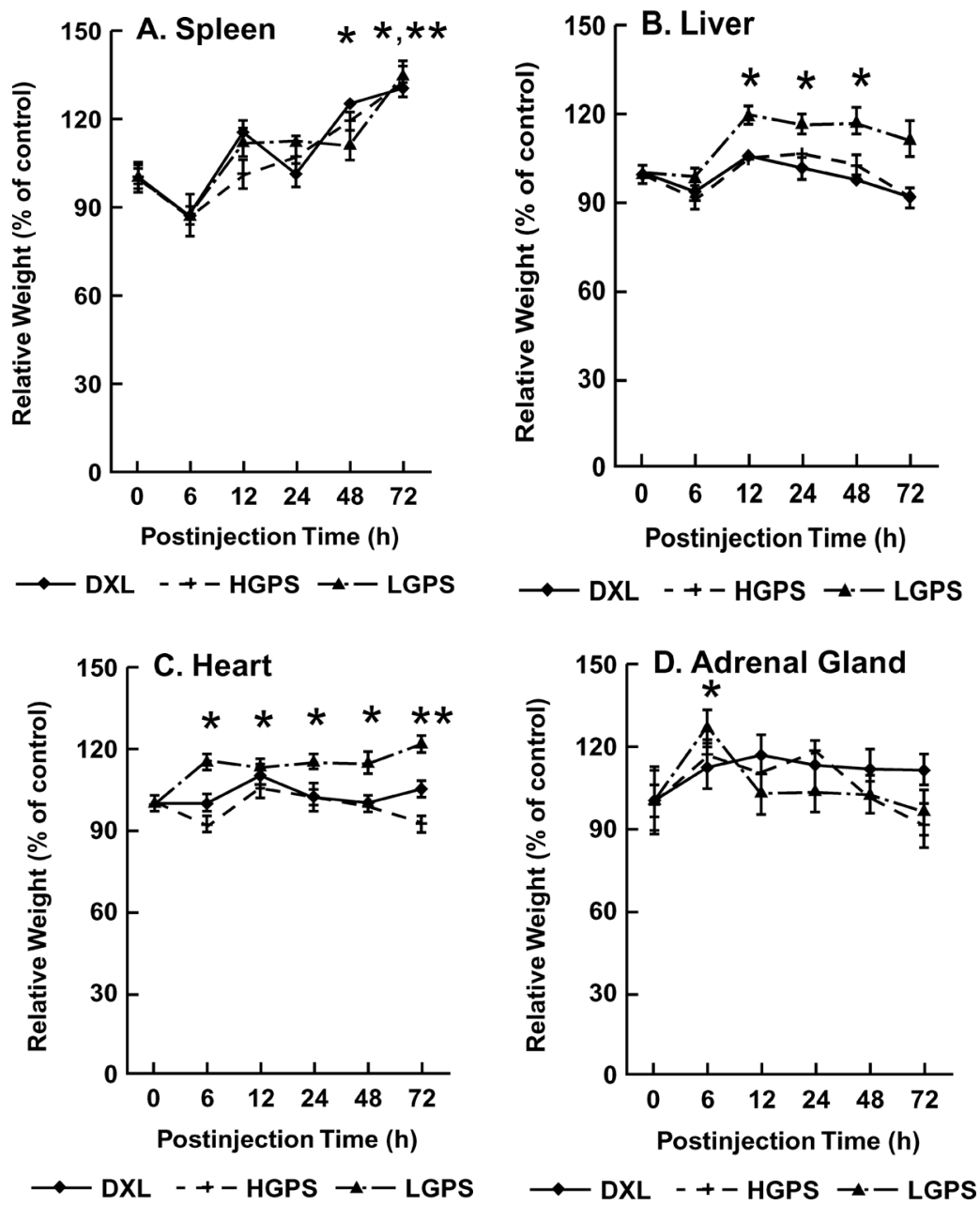

Fig. 2. Differential regulation of organ weight in different chicken lines following lipopolysaccharide (LPS) intravenous injection. The HGPS and LGPS hens were selected for high or low group productivity and survivability, respectively, and the DXL was commercial chicken line. Compared to their respective controls, spleen weight (A) was significantly increased in DXL chicks at $48 \mathrm{~h}(P<0.05)$ and $72 \mathrm{~h}(P<0.01)$ post-injection, while in both HGPS and LGPS chicks at $72 \mathrm{~h}$ post-injection $(P<0.05$, respectively); increased liver weight (B), heart weight (C), and adrenal gland weight (D) were found in LGPS chicks but not in both HGPS and DXL chicks from 12 to $48 \mathrm{~h}$ post-injection $(P<0.05), 6$ to $72 \mathrm{~h}(P<0.05$ and $P<0.01$, respectively), and at $6 \mathrm{~h}(P<0.05)$ post injection, respectively. ${ }^{*}=P<0.05$ and ${ }^{* *}=$ $P<0.01$ ( $n=10 /$ at each period in time for each line). 
The reason for the differing regulation of growth performance in the present lines could be related to each line's unique characteristics in response to stress. Previous studies showed that, compared to LGPS and DXL chickens, HGPS chickens had a better fast coping response to various stressors, such as social stress, handling and transport stress, and cold and heat stimulations (Hester et al., 1996 a, b, c; Cheng et al., 2001a, b, 2002). The HGPS chickens, compared to LGPS and DXL chickens, also had a stable neuroendocrine homeostasis in response to social stress, which could be related to their higher resistance to LPS stress (Cheng et al., 2002, 2003). In agreement with this hypothesis, Quan et al. (2001) and Carobrez et al. (2002) reported that impaired coping capability to social stress increases the susceptibility to LPS challenge in rodents and caused long-term consequences on animal well-being.

\subsection{LPS-induced different changes of body temperature in the different chicken lines}

The present study demonstrated that LPS-induced changes of core temperature (cloacal temperature) in chicks were strain and time dependent. Compared to each line's respective controls, LPS injection resulted in hypothermia in all of the treated chicks at $6 \mathrm{~h}$ postinjection regardless of the strain (Figure 3), but the greatest hypothermia was found in HGPS chicks (HGPS $<$ LGPS $<$ DXL, $P<0.001, P<0.01$, and $P<0.05$, respectively). At 12 h postinjection, LPS induced a significant hyperthermia in both DXL and LGPS chicks $(P<0.05$ and $P<0.01$, respectively) but not in HGPS chicks $(P=0.09)$. From 12 to $72 \mathrm{~h}$ post-injection, compared to their respective controls, the core temperature returned to normal in both DXL and HGPS chicks $(P>0.05)$, while LGPS chicks had a secondary hypothermia from 48 to $72 \mathrm{~h}$ post-injection $(P<0.01$ and $P<0.05$, respectively).

The present results showed that LPS injection induces changes in chickens' core temperature regardless of strain. However, each strain had a unique pattern of regulating core temperature in response to LPS immune stress (Figure 3). The HGPS chicks had transient monophasic hypothermia, the DXL chicks had a biphasic response showing an initial hypothermia followed by hyperthermia, and the LGPS chicks had a triphasic response showing an initial hypothermia, then hyperthermia, followed by a longer-lasting secondary hypothermia. Similar to the current results, previous studies found that LPS-induced different fever responses in birds, such as a monophasic hypothermia in chicks (Smith et al., 1978) and a biphasic response, i.e., an initial phase of hypothermia followed by a fever response, in chickens (Rotiroti et al., 1981), Japanese quail (Koutsos and Klasing, 2001), and pigeons (Nomoto, 1996). The LPS-induced biphasic and triphasic response were also found in rats (Derijk and Berkenbosch, 1994; Romanovsky et al., 1996) and mice (Kozak et al., 1994). The genetic bases of the different responses to the LPS immune stress between animals are likely to constitute an intrinsic characteristic of the animals' unique febrile response and could result from its capability to resist stress. The hypothesis is supported by the findings from the previous studies in which it was reported that psychological stress itself can induce an increase in core temperature, "psychogenic fever," in humans and animals (Oka et al., 2001).

The mechanism(s) of differential regulation of core temperature between the present lines could be related to each line's unique pattern in coping with stressors, such as the capability of behavioral and physiological plasticity including changes in the neuroendocrine and immune systems (Cheng et al., 2001a,b, 2002, 2003). A parallel study showed that LPS injection induced changes of pro-inflammatory interleukin (IL), such as IL-1 mRNA expressions, in the liver of 
all of the LPS-treated chicks (Eicher and Cheng, 2003), but LGPS chicks had a heavier liver than both DXL and HGPS chicks at 12 and $48 \mathrm{~h}$ post-injection, during which period LGPS chicks suffered from secondary hypothermia. These results may suggest that, in response to endotoxin challenge, the liver functions of LGPS chicks were increased and might have secreted a greater amount of IL-1 protein. The hypothesis agrees with the finding that the liver is a major source of IL in endotoxemia. The LPS-induced increase in the liver's metabolic function and increase in the release of acute phase proteins and cytokines including IL-1 have been reported in experimental animals including chickens (Xie et al., 2000).

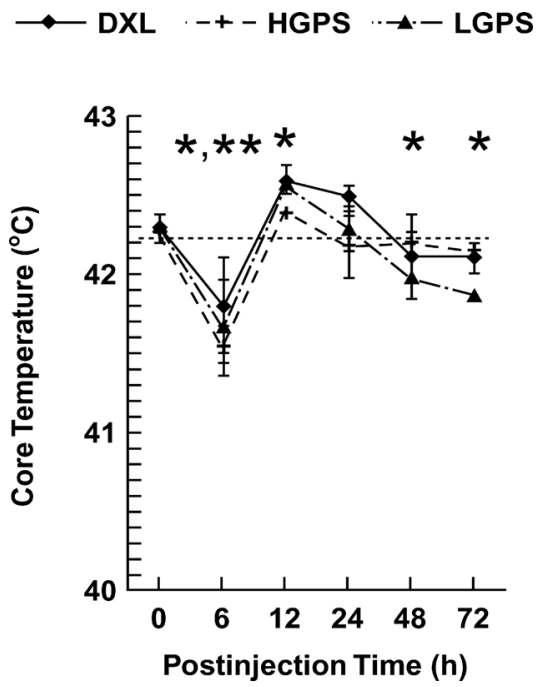

Fig. 3. Differential regulation of core temperature in different chicken lines following lipopolysaccharide (LPS) intravenous injection. The HGPS and LGPS hens were selected for high or low group productivity and survivability, respectively, and the DXL was commercial chicken line. Compared to their respective controls, LPS injection resulted in hypothermia in all of the treated chicks at $6 \mathrm{~h}$ post-injection, but the greatest reduction of core temperature was found in HGPS chicks $(P<0.05$ and $P<0.01$, respectively). By 12 h postinjection, both DXL and LGPS chicks but not HGPS chicks had hyperthermia. Core temperature returned to control levels at $24 \mathrm{~h}$ post injection in both DXL and HGPS chicks, while LGPS chicks had a secondary hypothermia from 48 to $72 \mathrm{~h}$ after injection $(P<0.05)$. * $P<0.05$ and $^{* *}=P<0.01(\mathrm{n}=10 /$ at each period in time for each line).

\subsection{LPS-induced different change of behavior in the different chicken lines}

The majority of significant behavioral differences between LPS and saline control groups were observed from 6 to $12 \mathrm{~h}$ post-injection. During this period, chicks were very inactive, as illustrated by a very large and significant increase in sitting $(P<0.001$, Figure 4a-e). Correspondingly, standing, feeding, drinking, and moving were all significantly lower during this time compared to control chicks. By $24 \mathrm{~h}$ post-injection, sitting, standing, feeding, and drinking returned to control levels (Figure $4 \mathrm{~b}-\mathrm{e}$ ). However, the amount of time spent sitting was increased again at $48 \mathrm{~h}$ post-injection in all of the treated chicks, with a time length in the order LGPS > HGPS > DXL (Figure 4e). The increase in sitting in LGPS chicks could be related 

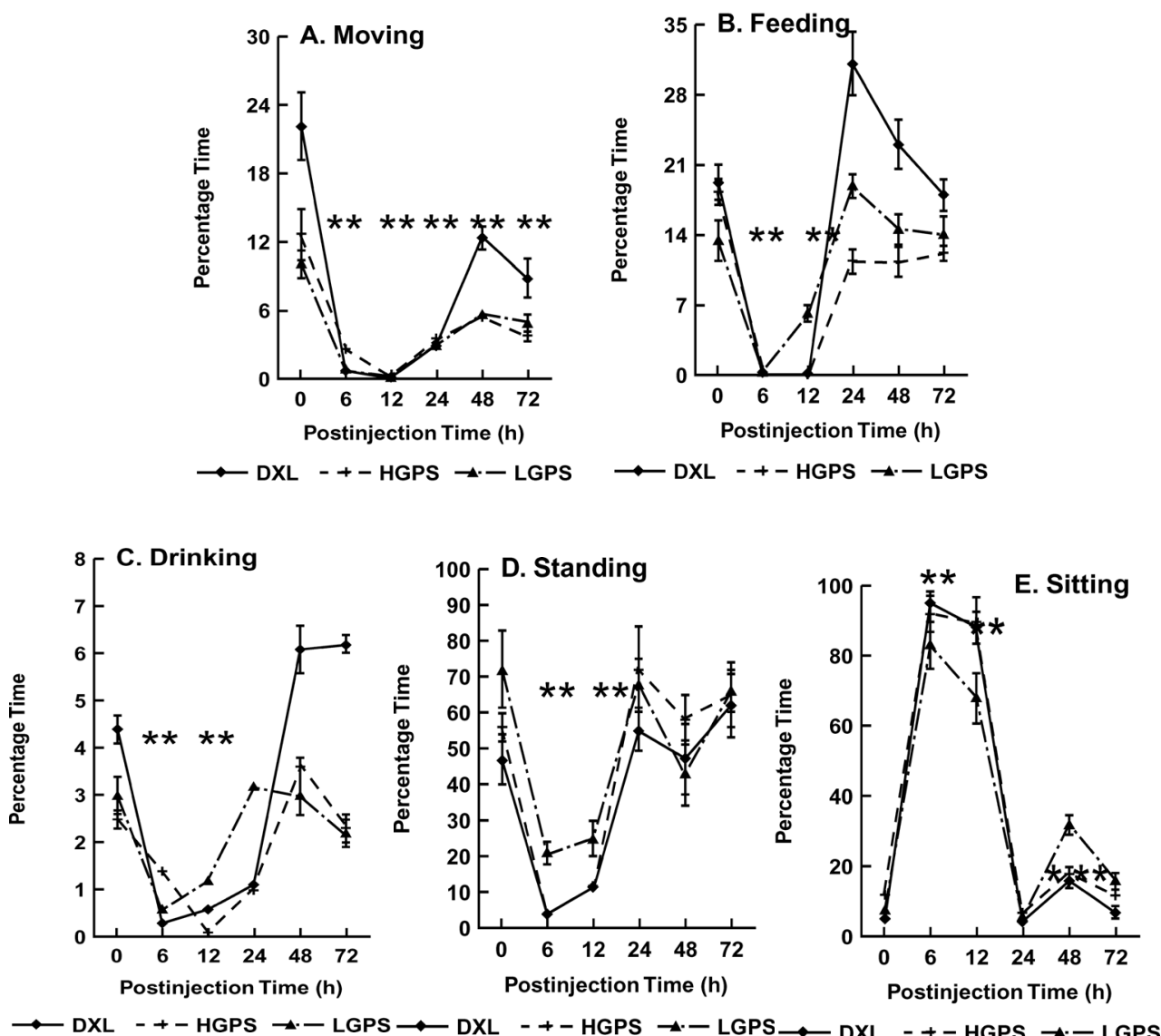

Fig. 4. Differential regulation of behavioral plasticity in different chicken lines following lipopolysaccharide (LPS) intravenous injection; A) movement, B) feeding, C) drinking, D) standing, and E) sitting. The HGPS and LGPS hens were selected for high or low group productivity and survivability, respectively, and the DXL was commercial chicken line. Compared to their respective controls, all of the treated chicks were very inactive at 6 to 12 $h$ post injection, as illustrated by a very large and significant increase in sitting $(P<0.01$, Figure 4a-e). Correspondingly, standing, feeding, drinking, and moving were all significantly lower during this time. By $24 \mathrm{~h}$ post injection, setting, standing, feeding, and drinking returned to the control levels (Figure $4 \mathrm{~b}-\mathrm{e}$ ). However, the amount of time spent sitting was increased again at $48 \mathrm{~h}$ post injection in all of the treated chicks in the order LGPS $>$ HGPS $>$ DXL $(P<0.05$ and $P<0.01$, respectively, Figure $4 \mathrm{e}) .{ }^{*}=P<0.05$ and ** $=$ $P<0.01(\mathrm{n}=10 /$ at each period in time for each line).

to their secondary peak of hypothermia, which started at $48 \mathrm{~h}$ post-injection (Figure 2). Interestingly, the amount of time that chicks spent moving was suppressed in all LPS-injected groups and had not returned to control levels even after $72 \mathrm{~h}$ post-injection, suggesting that there may still have been some mild effect from the LPS injection (Figure 4a). 


\section{Conclusion}

The LPS injection induced a series of sickness symptoms in the infected individuals at both behavioral and clinical levels, but the reactions were in a genotypic- and phenotypic-specific manner. Compared to both LGPS and DXL chicks, HGPS chicks had acute, transient behavioral and physical changes with less effect on BW gain and organ development. These results suggested that genetic selection for productivity and survivability may also have altered the mechanisms controlling the animals' immunity and stress response including LPS challenge. This hypothesis is in agreement with the previous findings that the genetic selection for one indicator could result in changes in other characteristics in animals including chickens. For instance, chickens selected for their high level of plasma corticosterone, compared to a reversely selected line, greatly resisted E. coli challenge (Gross and Siegel, 1975). Bayyari et al. (1997) also reported that genetic selection from increased body weight and egg production in turkeys affected their immune and physiological responses.

The present study provided evidence that genetic differences in chickens' productivity and behavioral styles were associated with hereditary plasticity of the behavioral and physiological homeostasis in response to LPS challenge. The LPS-induced alterations in behavioral and physical measurements were found in all of the three chicken lines, but the most pronounced changes were found in the LGPS line. The results demonstrated that, in chickens as in mammals, the cellular mechanisms regulating the response to LPS challenge are genotypic and phenotypic dependent. The differential responses between the present lines are consistent with the hypothesis that, in poultry, population differences exist in response to various stressors, and LPS challenge can be a useful indicator to evaluate the efficacy of immunity and capability to adapt infection in poultry. The present chicken lines may also provide a new animal model for biomedical investigation on the effects of genetics, epigenetics, and gene-environmental interactions on inflammatory disorders and infectious diseases.

\section{References}

Adler, H. E., and A. J. DaMassa. 1979. Toxicity of endotoxin to chicks. Avian Dis. 23:174-178.

Agrawal A, J. Tay, E.G. Yang, S. Agrawal, and S. Gupta. 2010. Age-associated epigenetic modifications in human DNA increase its immunogenicity. Aging 2:93-100.

Alexander, G. and E.T. Rietshel. 2001. Bacterial lipopolysccharides and innate immunity. J Endotoxin Res. 7:167-202.

Baccarelli, A. and V. Bollati. 2009. Epigenetics and environmental chemicals. Curr Opin Pediatr. 21:243-251.

Bauer, M.E. 2008. Chronic stress and immunosenescence: a review. Neuroimmunomodulation. 15:241-250.

Bayarsaihan, D. 2011. Epigenetic mechanisms in inflammation. J Dent Res 90:9-17.

Bayyari, G. R., W. E. Huff, N. C. Rath, J. M. Balog, L. A. Newberry, J. D. Villines, J. K. Skeeles, N. B. Anthony, and K. E. Nestor. 1997. Effect of the genetic selection of turkeys for increased body weight and egg production on immune and physiological responses. Poult. Sci. 76:289-296.

Bennett, W.M. 1999. Drug-related renal dysfunction in the elderly. Geriatr Nephrol Uro 19:21-25. 
Black, P.H. 1994. Immune system-central nervous system interactions: effect and immunomodulatory consequences of immune system mediators on the brain. Antimicrob Agents Chemother 38:7-12.

Bruunsgaard, H. and B.K. Pedersen. 2003. Age-related inflammatory cytokines and disease. Immunol Allergy Clin North Am. 23:15-39.

Buchenauer, D. 1990. Genetic behavioral aspects of agricultural animals. Dtsch. Tierarztl. Wochenschr. 97:247-9.

Buffum, M and J.C. Buffum. 2000. Nonsteroidal anti-inflammatory drugs in the ederly. Pain manag Nurs 12:40-50.

Candore, G., C. Caruso, E. Jirillo, T. Magrone, and S. Vasto. 2010. Low grade inflammation as a common pathogenetic denominator in age-related diseases: novel drug targets for anti-ageing strategies and successful ageing achievement. Curr Pharm Des 16:584-596.

Capone, M.L., S. Tacconelli, L.G. Rodriguez, and P. partrignani. 2010. NSAIDs and cardiovascular disease: transducing human pharmacology results into clinical readouts in the general population. Pharmacol Rep 62:530-535.

Carobrez, S. G., O. C. Gasparotto, B. Buwalda, and B. Bohus. 2002. Long-term consequences of social stress on corticosterone and IL-1beta levels in endotoxin-challenged rats. Physiol. Behav. 76:99-105.

Carrier E.J., S. Patel, and C.J. Hillard. 2005. Endocannabinoids in neuroimmunology and stress. Curr Drug Targets CNS Neurol Disord. 4:657-65.

Cevenini, E., C. Caruso, G. Candore, M. Capri, D. Nuzzo, G. Duro, C. Rizzo, G. ColonnaRomano, D. Lio, D. Di Carlo, M.G. Palmas, M. Scurti, E. Pini, C. Franceschi and S. Vasto. 2010. Age-related inflammation: the contribution of different organs, tissues and systems. How to face it for therapeutic approaches. Curr Pharm Des.16:609-618.

Cheng, H. W., G. Dillworth, P. Singleton, Y. Chen, and W. M. Muir. 2001a. Effect of Genetic Selection for Productivity and Longevity on Blood Concentrations of Serotonin, Catecholamines, and Corticosterone of laying hens. Poult. Sci. 80:1278-1285.

Cheng, H. W., S. D. Eicher, Y. Chen, P. Singleton, and W. M. Muir. 2001b. Effect of genetic selection for group productivity and longevity on immunological and hematological parameters of chickens. Poult. Sci. 80:1079-1086.

Cheng, H. W., P. Singleton, and W. M. Muir. 2002. Social stress in laying hens: differential dopamine and corticosterone responses after intermingling different genetic strains of chickens. Poult. Sci. 81:1265-72.

Cheng, H. W., P. Singleton, and W. M. Muir. 2003a. Social stress in laying hens: differential effect of stress on plasma dopamine concentrations and adrenal function in genetically selected chickens. Poult. Sci. 82:192-8.

Cheng, H.W., P. Singleton, and W.M. Muir. 2003b.Social stress differentially regulates neuroendocrine responses in laying hens: I. Genetic basis of dopamine responses under three different social conditions. Psychoneuroendocrinology 28:597-611.

Cheng, H.W. and W.M. Muir. 2004a. Chronic social stress differentially regulates neuroendocrine responses in laying hens: II. Genetic basis of adrenal responses under three different social conditions. Psychoneuroendocrinology. 97:961-971.

Cheng, H.W. R. Freire, and E.A. Pajor. 2004b. Endotoxin stress responses in chickens from different chicken lines. 1. Sickness, behavioral, and physical responses. Poultry Sci. 83:707-715. 
Cheng, H.W. and W.M. Muir. 2005. The effects of genetic selection for survivability and productivity on chicken physiological homeostasis. World's Poultry Science Journal, 61:383-397.

Chung, H.Y., E.K. Lee, Y.J. Choi, J.M. Kim, D.H. Kim, Y. Zhou, C.H. Kim, J. Lee, H.S. Kim, N.D. Kim, J.H. Jung, B.P. Yu. 2011. Molecular inflammation as an underlying mechanism of the aging process and age-related diseases. J Dent Res. 90:830-840.

Cohen, M.C., and S. Cohen. 1996. Cytokine function: A study in biological diversity. Am J Clin Pathol. 105:589-598.

Craig, J. V., W. F. Dean, G. B. Havenstein, K. K. Kruger, K. E. Nestor, G. H. Purchase, P. B. Siegel, and G. L. van Wicklen. 1999. Guidelines for poultry husbandry. Pages 55-66 in Guide for the Care and Use of Agricultural Animals in Agricultural Research and Teaching. Federation of Animal Science Societies. Savoy, Illinois, USA.

Dantzer, R., R. M. Bluthe, G. Gheusi, S. Cremona, S. Laye, P. Parnet, and K. W. Kelley. 1998. Molecular basis of sickness behavior. Ann. N. Y. Acad. Sci. 856:132-138.

Derijk, R. H., and F. Berkenbosch. 1994. Hypothermia to endotoxin involves the cytokine tumor necrosis factor and the neuropeptide vasopressin in rats. Am. J. Physiol. 266:R9-14.

Duff, G.W. 2007. Influence of genetics on disease susceptibility and progression. Nutr Rev 65:S177-181.

Dubousset J, Machida M. (2001) Possible role of the pineal gland in the pathogenesis of idiopathic scoliosis. Experimental and clinical studies. Bull Acad Natl Med. 185:593-602.

Eicher, S. D., and H. W. Cheng. 2003. Toll-like receptor 2 and acute phase cytokine responses by genetically selected chickens following an LPS challenge. J. Fed. Am. Soc. Exp.1 Biol. 17:C51 (Abstr.).

Fessler, M.B., K.C. Malcolm, M.W. Duncan, and G.S. Worthen. 2002. A genomic and proteomic analysis of activation of the human neutrophil by lipopolysaccharide and its mediation by p38 mitogen-activated protein kinase. J Biol Chem. 277:3129131302.

Franceschi, C., M. Bonafe, S. Valenisin, F. Olivieri, M. De Luca, E. Ottavini, and G. De Benedictis. 2000. Inflamm-aging. An evolutionary perspective on immunoscenscence. Ann N Y Acad Sci. 908:244-254.

Freire, R., P. Singleton, Y. Chen, M. W. Muir, Ed. Pajor, and H. W. Cheng. 2001. The relationship between physiological parameters and behavioral response to social stress among three genetic lines of laying hens. Poult. Sci. 80 (Suppl. 1):280 (Abstr.).

Gross, W. B., and P. B. Siegel. 1975. Immune response to Escherichia coli. Am. J. Vet. Res., 36:568-571.

Gross, W. B., and H. S. Siegel. 1983. Evaluation of the heterophil/lymphocyte ratio as a measure of stress in chickens. Avian Dis. 27:972-979.

Gruver, A.L., L.L. Hudson, and G.D. Sempowski. 2007. Immunosenescence of saging. J Pathol 211:114-156.

Hatchwell, E. and J.M. Greally, 2007. The potential role of epigenetic dysregulation in complex human disease. Trends in Genet 23:588-595.;

Hester, P. Y., W. M. Muir, J. V. Craig, and J. L. Albright. 1996a. Group selection for adaptation to multiple-hen cages: hematology and adrenal function. Poult. Sci. 75:1295-1307. 
Hester, P. Y., W. M. Muir, J. V. Craig, and J. L. Albright. 1996b. Group selection for adaptation to multiple-hen cages: production traits during heat and cold exposures. Poult. Sci. 75:1308-1314.

Hester, P. Y., W. M. Muir, and J. V. Craig. 1996c. Group selection for adaptation to multiplehen cages: humoral immune response. Poult. Sci. 75:1315-1320.

Hurnik, J.F., A.B. Webster, and P.B. Siegel. 1995. Dictionary of farm animal behavior. $2^{\text {nd }}$ ed. Iowa State University Press/Ames, USA

Johnson, R. W. 1998. Immune and endocrine regulation of food intake in sick animals. Domest Anim. Endocrinol. 15:309-319.

Khatami, M. 2008. "Yin and Yang' in inflammation: duality in innate immune cell function and tumorigenesis. Expert Opin Biol Ther. 8:1461-1472.

Khatami, M. 2011.Unresolved inflammation: immune 'tsunami' or erosion of integrity in immune-privilege and immune-responsive tissues and acute and chronic inflammatory diseases or cancer. Expert Opin Biol Ther. (Epub ahead of print).

Knight, J.C. 2005. Regulatory polymorphisms underlying complex disease traits. J Mol Med. 83:97-109.

Koutsos, E. A., and K. C. Klasing. 2001. The acute phase response in Japaneses quail (Coturnix coturnix japonica) Comp. Biochem. Physiol. 128:255-263.

Kozak, W., C. A. Conn, and M. J. Kluger. 1994. Lipopolysaccharide induces fever and depresses locomotor activity in unrestrained mice. Am. J. Physiol. 266:R125-135.

Larson, C.T, W.B. Gross, and J.W. Davis. 1985. Social stress and resistance of chicken and swine to 49:208-10.

Laurin, D. E., and K. C. Klasing. 1987. Effects of repetitive immunogen injections and fasting feeding on iron, zinc, and copper metabolism. Biol. Trace Elem. Res. 14:153-165.

Leininger, M. T., C. A. Portocarrero, C. A. Bidwell, M. E. Spurlock, J. N. Nielsen, and K. L. Houseknecht. 1998. Effect of immune challenge on different genotypes: How sick do they get? Purdue University Swine Day Report. Purdue University, Indiana.

Leon, L. R., 2002. Molecular Biology of thermoregulation invited review: cytokine regulation of fever studies using gene knockout mice. J. Appl. Physiol. 92:2648-2655.

Lipton, S.A., Z. Gu and T. Nakamura. 2007. Inflammatory mediators leading to protein misfolding and uncompetitive/fast off-rate drug therapy for neurodegenerative diseases. Int Rev neurobiol 82:1-27.

Loktionov, A. 2003. Common gene polymorphisms and nutrition: emerging links with pathogenesis of multifactorial chronic diseases (review). J Nutr Biochem. 14:426451.

Lu, Q., X. Qiu, N. Hu, H. Wen, Y. Su and B.C. Richardson. 2006. Epigenetics, disease, and therapeutic interventions. Ageing Res Rev. 5:449-467.

Macari, M., R. L. Furlan, F. P. Gregorut, E. R. Secato, and J. R. Guerreiro. 1993. Effects of endotocin, interleukin-1 beta and prostaglandin injections on fever responses in broilers. Br. Poult. Sci. 34:1035-1042.

Maroon, J.C., J.W. Bost and A. Maroon. 2010. natural anti-inflammatory agents for pain relief. Surg Neurol Int 1:80.

Maxwell, M. H., and R. B. Burns. 1986. Experimental stimulation of eosinophil production in the domestic fowl (Gallus gallus domesticus). Res. Vet. Sci. 41:14-23.

McGeer, P.L. and E.G. McGeer. 2004. Inflammation nd the degenerative diseases of aging. Ann N Y Acad Sci 1035:104-116. 
McNaull BB, Todd S, McGuinness B, Passmore AP. 2010. Inflammation and anti-inflammatory strategies for Alzheimer's disease--a mini-review. Gerontology. 56:3-14.

Menkes, C.J. 1989. Renal and hepatic effects of NSAIDs in the elderly. Scand J Rheumatol Suppl 83:11-13.

Migicovsky, Z. and I.Kovalchuk. 2011. Epignetic memory in mammals. Front in Genet 2:1-7.

Mill, J. 2011. Toward an integrated genetic and epigenetic approach to Alzhemer's disease. Neurobiol Aging 32:1188-1191.

Muir, W.M. 2005. Incorporation of competitive effects in forest tree or animal breeding programs. Genetics, 170:1247-259.

Muir, W. M., and J. V. Craig. 1998. Improving animal well-being through genetic selection. Poult. Sci. 77:1781-1788.

Muir, W.M. and A. Schinckel. 2002. Incorporation of competitive effects in breeding programs to improve productivity and animal well being. Proc. 7th World Congress of Genetics Applied to Livestock Breeding. Pp. 35-6

Norman, A.W. 1990. The avian as an animal model for the study of the vitamin D endocrine system. J Exp Zool Suppl. 4:37-45.

National Research Council. 1994. Nutrient Requirements of Poultry. 9th rev. ed. National Academy Press, Washinton, D. C.

Naumova, E., A. Mihaylova, M. Ivanova, S. Michailova, K. Penkova and D. Baltadjieva. 2004. Immunological markers contributing to successful aging in Bulgarians. Exp gerontology 39:637-644.

Nomoto, S. 1996. Diurnal variations in fever induced by intravenous LPS injection in pigeons. Pflugers Arch. 431:987-989.

Oka, T., K. Oka, and T. Hori. 2001. Mechanisms and mediators of psychological stressinduced rise in core temperature. Psychosom. Med. 63:476-486.

Pastinen, T. and T.J. Hudson. 2004. Cis-acting regulatory variation in the human genome. Science, 306:647-650.

Paweleec, G. and A. Larbi. 2008. Immunity and ageing in man: Annual review 2006/2007. Exp Gerontology, 43:34-38.

Pearce, E.L. and H. Shen. 2006. Making sense of inflammation, epigenetics, and memeory CD8+ T-cvell differentiation in the context of infection. Immunol Rev. 211:197-202.

Pes, G.M., D. Lio, C. Carru, L. Deiana, G. Baggio, C. Franceschi, L. Ferrucci, F. Oliveri, L. Scola, A. Crivello, G. Candore, G. Colonna-Romano and C. Caruso. 2004. Association between longevity and cytokine gene polymorphisms. A study in Sardinian centenarians. Aging Clin Exp Res. 16:244-8.

Petronis, A. 2001. Human morbid genetics revisited: Relevance of epigenetics. Trends Genet. 17:142-146.

Plata-Salaman, C. R., E. Peloso, and E. Satinoff. 1998. Interleukin-1 beta-induced fever in young and old Long-Evans rats. Am. J. Physiol. 275:R1633-1638.

Quan, N., R. Avitsur, J. L. Stark, L. He, M. Shah, M. Caligiuri, D. A. Padgett, P. T. Marucha, and J. F. Sheridan. 2001. Social stress increases the susceptibility to endotoxic shock. J. Neuroimmunol. 115:36-45.

Rotiroti, D., A. Foca, P. Mastroeni, D. Fumarola, and G. Nistico. 1981. Behavioural and body temperature effects of meningococcal lipopolysaccharide after intraventricular injection in adult fowls Gallus domesticus. Res. Commun. Chem. Pathol. Pharmacol. 33:395-402. 
Romanasky, A. A., V. A. Kulchitsky, C. T. Simons, and N. Sugimoto. 1996. Mehodology of fever research: why are polyphasic fevers often thought to be biphasic? Am. J. Physiol. 275:R332-338.

Salvioli, S., S. Capri M, Valensin, P. Tieri, D. Monti, E. Ottaviani, and C. Franceschi. 2006. Inflamm-aging, cytokines and aging: state of the art, new hypotheses on the role of mitochondria and new perspectives from systems biology. Curr Pharm Des. 12:3161-3171.

SAS Institute. 1992. SAS User's Guide to the Statistical Analysis System. North Carolina State University, Raleigh, NC.

Sastre, M. and S.M. Gentleman. 2010. NSAIDs: how they work and their prospects as therepeutics in Alzhermer's disease. Frontier in Aging Neurosci 2: 1-6.

Sergio, G. 2008. Exploring the complex relations between inflammation and aging (inflammaging): anti-inflamm-aging remodeling of inflamm-aging, from robustness to frailty. Inflamm res. 57:558-563.

Sherman, S., R. Fuldner, J. Carrington, M. Miller, and A. Monjan. 2005. Workshop summary. NIA Workshop on Inflammation, Inflammatory Mediators, and Aging. Bethesda, Maryland, September 1-2. \{re[ared by R. Li and Associates, Inc.

Siegel, P. B., and E. A. Dunnington. 1997. Genetic selection strategies--population genetics. Poult. Sci. 76:1062-5.

Smith, I. M., S. T. Licence, and R. Hill. 1978. Haematological, serological and pathological effects in chicks of one or more intravenous injections of Salmonella gallinarum endotoxin. Res. Vet. Sci. 24:154-160.

Sternberg EM. 2006. Neural regulation of innate immunity: a coordinated nonspecific host response to pathogens. Nat Rev Immunol. 6:318-28.

Tang, W.Y. and S.M. Ho 2007. Epigenetic reprogramming and imprinting in origins of disease. Rev Endocr Metab Disord 8:173-182.

Tiihonen, K., S. Tynkkynen, A. Ouwehand, T. Ahlroos, and N. Rautonen. 2008. The effect of ageing with and without non-steroidal anti-inflammatory drugs on gastrointestinal microbiology and immunology. Br J Nutr. 100:130-137.

Turko, A.J., R.L. Earley and P.A. wright. 2011. Behaviour drives morphology: voluntary emersion patterns shape gill structure in generetically identical mangrove rivulus. Animal Behav. 82:39-47.

Turnbull, A.V. and L. Catherine. 1999. Regulation of the hypothalamic-pituitary-adrenal axis by cytokines: actions and mechanisms of action. Physiol Rev. 79:1-71.

Vasto, S., G. Candore, C.R. Balistreri, M. Caruso, G. Colonna-Romano, M.P. Grimaldi, F. Listi, D. Nuzzo, D. Lio and C. Caruso. 2007. Inflammatory networks in ageing, agerelated diseases and longevity. Mech Ageing Dev.128:83-91.

vel Szic, K.S., M.N. Ndlovu, G. Haegeman and W. Vanden Berghe. 2010. Nature or nurture: let food be your epigenetic medicine in chronic inflammatory disorders. Biochem Pharmacol. 80:1816-1832.

Vogt, G., M. Huber, M. Thiemann, G. van den Boogaart, O.J. Schmitz, and C.D. Schubart. 2008. Production of different phenotypes from the same genotype in the same environment by developmental variation. J Exp Biol. 211:510-523.

Wilson, A.G. 2008. Epigenetic regulation of gene expression in the inflammatiory response and relevance to common diseases. J Periodontol, 79:1514-1519. 
Woolaston, R. R., P. Manueli, S. J. Eady, I. A. Barger, L. F. Le Jambre, D. J. Banks, and R. G. Windon. 1996. The value of circulating eosinophil count as a selection criteria for resistance of sheep to trichostrongyle parasites. Int. J. Parasitol. 26:123-126.

Xie, H., N. C. Rath, G. R. Huff, W. F. Huff, and J. M. Balog. 2000. Effects of Salmonella typhimurium lipopolysaccharide on broiler chickens. Poult. Sci. 79:33-40. 


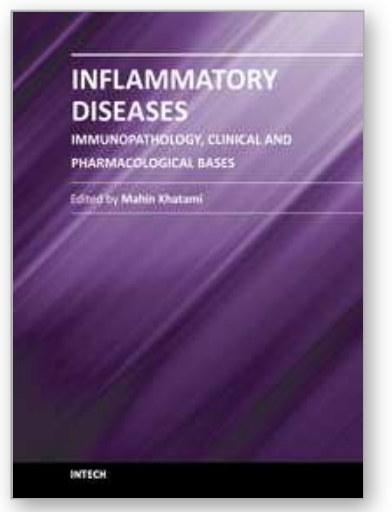

\author{
Inflammatory Diseases - Immunopathology, Clinical and \\ Pharmacological Bases \\ Edited by Dr Mahin Khatami
}

ISBN 978-953-307-911-0

Hard cover, 396 pages

Publisher InTech

Published online 10, February, 2012

Published in print edition February, 2012

This book is a collection of comprehensive reviews contributed by experts in the diverse fields of acute and chronic inflammatory diseases, with emphasis on current pharmacological and diagnostic options. Interested professionals are also encouraged to review the contributions made by experts in a second related book entitled "Inflammation, Chronic Diseases and Cancer"; it deals with immunobiology, clinical reviews, and perspectives of the mechanisms of immune inflammatory responses that are involved in alterations of immune dynamics during the genesis, progression and manifestation of a number of inflammatory diseases and cancers, as well as perspectives for diagnosis, and treatment or prevention of these disabling and potentially preventable diseases, particularly for the growing population of older adults around the globe.

\title{
How to reference
}

In order to correctly reference this scholarly work, feel free to copy and paste the following:

Heng-wei Cheng (2012). Genetic Variation in Resistance to Inflammation and Infectious Disease, Inflammatory Diseases - Immunopathology, Clinical and Pharmacological Bases, Dr Mahin Khatami (Ed.), ISBN: 978-953307-911-0, InTech, Available from: http://www.intechopen.com/books/inflammatory-diseasesimmunopathology-clinical-and-pharmacological-bases/genetic-variation-in-resistance-to-infection-andinflammation-

\section{INTECH}

open science | open minds

\author{
InTech Europe \\ University Campus STeP Ri \\ Slavka Krautzeka 83/A \\ 51000 Rijeka, Croatia \\ Phone: +385 (51) 770447 \\ Fax: +385 (51) 686166 \\ www.intechopen.com
}

\author{
InTech China \\ Unit 405, Office Block, Hotel Equatorial Shanghai \\ No.65, Yan An Road (West), Shanghai, 200040, China \\ 中国上海市延安西路65号上海国际贵都大饭店办公楼 405 单元 \\ Phone: +86-21-62489820 \\ Fax: +86-21-62489821
}


(C) 2012 The Author(s). Licensee IntechOpen. This is an open access article distributed under the terms of the Creative Commons Attribution 3.0 License, which permits unrestricted use, distribution, and reproduction in any medium, provided the original work is properly cited. 